\title{
Contribution to the knowledge on the distribution of freshwater sponges - the Danube and Sava rivers case study
}

\author{
Stefan ANDJUS,${ }^{1 *}$ Nadja NIKOLIC, ${ }^{2}$ Valerija DOBRICIC, ${ }^{3}$ Ana MARJANOVIC,${ }^{3}$ Zoran GACIC,${ }^{4}$ Goran BRANKOVIC, 5 \\ Maja RAKOVIC, ${ }^{1}$ Momir PAUNOVIĆ ${ }^{1}$
}

${ }^{1}$ Institute for Biological Research "Siniša Stanković", University of Belgrade, Bulevar despota Stefana 142, Belgrade; ${ }^{2}$ Department of Human Genetics, School of Dental Medicine, University of Belgrade, Dr. Subotica 8, Belgrade; ${ }^{3}$ Laboratory for Genetics, Institute of Neurology, School of Medicine, University of Belgrade, Dr. Subotica 6, Belgrade; ${ }^{4}$ Department of Natural Resources and Environmental Sciences, Institute for Multidisciplinary Research, University of Belgrade, Bulevar despota Stefana 142, Belgrade; ${ }^{5}$ Department of Materials Science, Institute Mihajlo Pupin, University of Belgrade, Volgina 15, 11060 Belgrade, Serbia

*Corresponding author: stefan.andjus@ibiss.bg.ac.rs

\begin{abstract}
Sponges in the large rivers within the Danube River Basin (DRB) have not been adequately studied. Hence, the aim of this work was to undertake an investigation on the distribution of sponge species in the Danube and Sava rivers. Out of 88 localities covered by the study, sponges were found at 25 sites only (46 samples in total). By using morphological (light and scanning electron microscopy) and genetic (28S rDNA sequencing) analysis, four species were determined: Ephydatia fluviatilis (Linnaeus, 1759), Spongilla lacustris (Linnaeus, 1759), Eunapius fragilis (Leidy, 1851), Trochospongilla horrida Weltner, 1893. In the Danube, the predominant species was found to be E. fluviatilis making approximately $80 \%$ of collected samples, while in the Sava River S. lacustris dominated, representing $46 \%$ of the river sponges. Our work represents one of the few studies on freshwater sponges within the DRB from long stretches of the large lowland rivers (more than $2500 \mathrm{~km}$ of the Danube River and about $900 \mathrm{~km}$ of the Sava River). Moreover, molecular analysis for the identification of freshwater sponges was applied on the material collected from a wide area, thus contributing to the systematic studies on the distribution and abundance of the European freshwater invertebrate fauna in general.
\end{abstract}

Key words: Freshwater Porifera; distribution; Danube; Sava; spicules.

Received: June 2017. Accepted: December 2017.

\section{INTRODUCTION}

Sponges (Porifera) constitute one of the most diverse metazoan phyla, with more than 8500 known species (Van Soest et al., 2012) and about 17,000 to 29,000 yet to be described (Itskovich et al., 2013; Morrow et al., 2013). Though the great majority of sponge species inhabit marine ecosystems, 237 species from 47 genera grouped in 7 families of the order Spongillida (Manconi and Pronzato, 2002) can be found in freshwater environments, the Neotropical region showing the highest richness in species, followed by Palearctic (Manconi and Pronzato, 2002, 2016; Manconi et al., 2013). Sponges are sessile organisms that represent an important component of aquatic ecosystems, with a significant filtering potential important for natural processes of water purification. They filter particles of a smaller size than other benthic invertebrates (Frost, 1978; Francis and Poirrier, 1986), ranging from zoo-phyto-pico plankton to bacteria (Manconi and Pronzato, 2015). Since they populate a diverse array of habitats and thrive in waters with different levels of pollution they may be used as water quality bioindicators (Rao et al., 2009). Some papers suggest their applicability in the measurement of levels of heavy metals in the water (Richelle, 1995). Their fossil spicules found in the sediment are a useful indicator of paleoenvironmental changes (Manconi and Pronzato, 2015). They have also proved to be valuable objects for biodiversity monitoring as suggested for freshwater environments of South America (Volkmer-Ribeiro and Machado, 2007) and Africa (Manconi and Pronzato, 2007). They are also of great interest for the pharmaceutical industry as they contain various bioactive compounds with anti-tumor, anti-infective and antiinflammatory properties (Van Soest et al., 2012). The biochemical pathways of synthesis of these compounds are often unknown (Roovere et al., 2006) and since sponges can be grown and develop in vitro from their resting bodies (gemmules), they are a good experimental model for studying these biochemical pathways as well (Lopp et al., 2007).

Studies on freshwater sponges in Europe have been marked by periods of essential discoveries with intermissions of lesser interest. Among the first studies on European Porifera were those by Annandale conducted in Scotland at the beginning of the $20^{\text {th }}$ century. The 
knowledge on sponges in Europe has been later considerably broadened by contributions of Arndt (1926, 1931, 1932a, 1932b). In more recent decades important papers have been published covering a number of European countries and their freshwater systems: Denmark and Iceland (Tendal, 1967a, 1967b, 1976), Romania (Rudescu, 1975), Belgium (Richelle-Maurer et al., 1994), Switzerland (Manconi and DesqueirouxFaundez, 1999), Spain (Traveset, 1990), Italy (Manconi and Pronzato, 1994), Norway (Økland and Økland, 1996), Germany (Gugel, 2001), Estonia (Roovere et al., 2006), Austria (Dröscher and Waringer, 2007), etc. More specifically, when considering inland waters of Central Europe, six sponge species have been recorded: Ephydatia fluviatilis (Linnaeus, 1759), Spongilla lacustris (Linnaeus, 1759), Eunapius fragilis (Leidy, 1851), Trochospongilla horrida Weltner, 1893, Ephydatia muelleri (Lieberkühn, 1856) and Heteromeyenia stepanowii (Dybowski, 1884) (Gugel, 2001; Dröscher and Waringer, 2007).Interestingly, the Balkan Peninsula, drained by many rivers and generally characterized by great diversity and complexity of aquatic fauna (Bănărescu, 2004), has not been, with few exceptions, systematically screened for the presence of freshwater sponges. Besides the capital work of Rudescu (1975) on Porifera Potamospongiae in Romania, few studies have been published from this area. For instance, a study on sponges from large Macedonian lakes Prespa, Dojran and Ohrid, has reported on Eunapius carteri (Bowerbank, 1863), S. lacustris, E. fluviatilis, E. fragilis, Spongilla prespensis Hadzische, 1953, Spongilla stankovici Arndt, 1938, Ochridaspongia rotunda Arndt, 1937 (Hadzisce, 1953), as well as on a troglobiotic freshwater sponge found in the karst of the Dinarid region of Croatia, Eunapius subterraneus Sket \& Velikonja, 1984 (Bănărescu, 2004; Bilandžija et al., 2007).

Regarding Sava and Danube, which belong to both Central Europe and the Balkans, data are again very limited. Several older (Matoničkin et al., 1975; Mihaljević et al., 1998) and more recent (Graf, 2015, Lucić, 2015) comprehensive and large-scale surveys of Sava and Danube rivers have been conducted, dealing with various aspects of their ecology. These studies included an indepth analysis of macroinvertebrates pointing again to the taxa richness, but with extremely scarce data, if any, on freshwater sponges. Just recently Anđus et al. (2016) gave preliminary findings on S. lacustris and E. fluviatilis in the Serbian stretch of the Danube. Also, in the Danube basin management plan of Croatia, several sponge species have been listed, without further analysis (E. fragilis, $E$. carteri, E. fluviatilis, E. Muelleri, S. lacustris, E. subterranea (Croatian Water Management Plan, 2013).

This prompted us to conduct the present study with the aim to contribute to the knowledge on Porifera distribution along considerable stretches of the Danube $(2580 \mathrm{~km})$ and Sava $(900 \mathrm{~km})$ rivers, with emphasis on less explored areas. For higher accuracy of species identification, in addition to the classic approach that relies on morphological characters, genetic analysis was also used.

\section{METHODS}

Basic physical and chemical properties such as $\mathrm{pH}$, temperature, dissolved oxygen and conductivity were determined on the spot, using HANNA HI $9126 \mathrm{pH}, \mathrm{HI}$ 9146, and HI98130 instruments, and TFA EN 13485 Digital thermometer. The concentration of nitrates, phosphates and ammonium salts were measured from water samples brought to the laboratory, using WTW chemical kits as recommended by manufacturer, and WTW Photo Lab Spectral spectrophotometer.

Sponge samples were collected during chemical and biological monitoring of the Sava and Danube rivers in the framework of GLOBAQUA project (Navarro-Ortega et al., 2015), and Joint Danube Survey 3 investigation (Graf, 2015) respectively in the period 2013-2015. A total of 68 locations were explored on the Danube River, and sponges were found at 17 of them. The Sava River was studied at 20 locations, from Slovenia to Serbia, and samples were found and collected at 7 sites. Potential finding sites, characterized by reduced flow, rocky bed and wood debris, referred to as "characteristic habitats", were visually inspected either from a boat, by wader walking or free diving. Samples were collected at depths between 0-5 m on river stretches of about 100 by $1 \mathrm{~m}$ along the river side. About 50 rocks, branches or other submerged objects were inspected per locality. Fragments from each sample were taken for spicule preparation and genetic analysis. An initial assessment of sample preservation quality in different media was done ( $4 \%$ formaldehyde, $70 \%$ ethanol, and dried). The type of preservation had no impact on spicule preparation, while the quality and yield of DNA was greatest in samples stored in 70\% ethanol, which led to later use of ethanol only.

For the assessment of relative abundance (substrate coverage) of sponges, an adaptation of the approach suggested by Dorschner et al., (1993) was implemented. In brief, the following criteria were applied:

small single colonies (level 1): only one or few specimens found within transecton site; several colonies (level 2): $\leq 10$ specimens per transect; numerous colonies (level 3): more than 10 specimens per transect. No greater coverage was registered.

The nitric acid technique as described by Manconi and Pronzato (2015), was used to dissolve sponge tissue and prepare spicules for light microscope analysis. Briefly, 2$5 \mathrm{~mm}$ sponge fragments were washed with ethanol, dried 
and fed into labeled glass tubes. They were then carefully topped with $2-5 \mathrm{~mL}$ of concentrated nitric acid $\left(\mathrm{HNO}_{3}\right)$ and left to decompose for $24 \mathrm{~h}$. The acid was then removed by pipette and the spicule residues were washed repeatedly with distilled water. Finally, the spicules were rinsed with and resuspended in $96 \%$ ethanol. A drop of suspension was then placed on a cover slip. When the alcohol dried, the cover slip was placed over the microscope slides with a drop of Canada balsam and heated to complete the preparation.

Drops of spicule suspension in ethanol were placed on specimen holders and coated with gold in a gold sputter at $18 \mathrm{~mA}$ for $1 \mathrm{~min}$. The specimens were analyzed and photographed in a VEGA TS 5133MM Scanning Electron Microscope (SEM), high vacuum mode using the SE detector with accelerating voltage.

Specimens for the extraction of genomic DNA were airdried at $56^{\circ} \mathrm{C}$ for $1 \mathrm{~h}$, and homogenized in 1:5 (weight:volume) lysis solution containing: $4 \mathrm{M}$ guanidine hidrochloride, $50 \mathrm{mM}$ Tris- $\mathrm{HCl} \mathrm{pH}$ 8.0, $0.05 \mathrm{M}$ EDTA, 20 $\mu \mathrm{g} \mu \mathrm{L}^{-1}$ of proteinase $\mathrm{K}$ and $1 \% \beta$-mercaptoethanol. The suspension was incubated at $50^{\circ} \mathrm{C}$ for $1 \mathrm{~h}$. An equal volume of phenol:chloroform:isoamyl alcohol (25:24:1) was added and nucleic acids were precipitated from the upper aqueous phase with 2 volumes of ethanol and $110^{-1}$ volume of sodium acetate. The pellet was washed in $70 \%$ ethanol, airdried and dissolved in nuclease-free water.

A fragment of approximately $340 \mathrm{bp}$ (base pairs) corresponding to the D3 domain of sponge 28S rDNA together with the highly conserved region of approximately $150 \mathrm{bp}$ was amplified using the following pair of primers (forward 5'-GAC CCG TCT TGA AAC ACG GA-3' and reverse 5'-TCG GAG GGA ACC AGC TAC TA-3') as previously described (Roovere et al., 2006; Lopp et al., 2007). The PCR amplifications were performed in $25 \mu \mathrm{L}$ reaction volumes containing about $100 \mathrm{ng}$ of sponge DNA, $2.5 \mathrm{mM} \mathrm{MgCl} 2,200 \mu \mathrm{M}$ each of dATP, dCTP, dGTP, and dTTP, $0.5 \mu \mathrm{M}$ of each primer and one unit of Taq polymerase. The DNA was denatured at $95^{\circ} \mathrm{C}$ for $1 \mathrm{~min}$, followed by 35 cycles of denaturation at $94^{\circ} \mathrm{C}$ for $45 \mathrm{~s}$, annealing at $55^{\circ} \mathrm{C}$ for $45 \mathrm{~s}$, and extension at $72^{\circ} \mathrm{C}$, for $1 \mathrm{~min}$, with a final extension at $72^{\circ} \mathrm{C}$ for 5 min. The presence of PCR products was confirmed by electrophoresis in $8 \%$ polyacrylamide gel.

The amplification products were directly sequenced in forward and reverse directions using the ABI Big Dye Terminator chemistry and an ABI 3500 instrument (Applied Biosystems, Foster City, CA). For the detection of defects and polymorphic sites on the ends of the sequences we used Sequencher 5.4.6. software (Trial free version). Comparison of the obtained sequences with sequences in the GenBank database was performed using the Basic Local Alignment Tool (BLAST), available at http://www.ncbi.nlm.nih.gov. Sequences were aligned using the program Clustal W with the parameters provided in the software package MEGA (Kumar et al., 2016).

The Neighbor-Joining (NJ) tree was obtained using MEGA 7 software (Saitou and Nei, 1987). The percentage of replicate trees in which the associated specimens clustered together in the bootstrap test (1000 replicates) is shown next to the branches (Felsenstein, 1985). The analysis involved 25 nucleotide sequences with a total of $258 \mathrm{bp}$ in the final dataset. The tree is drawn to scale, with branch lengths in the same units as those of the evolutionary distances used to infer the phylogenetic tree. The evolutionary distances were computed using the Kimura 2-parameter method (Kimura, 1980) and are in the units of the number of base substitutions per site.

\section{RESULTS}

Basic physical and chemical characteristics (such as water temperature, $\mathrm{pH}$, conductivity and dissolved oxygen) of the Danube and Sava Rivers at the explored sites are given in Tab. 1. Biological monitoring of Sava and Danube rivers revealed scarce and uneven distribution of freshwater sponges. Out of 88 inspected localities in total at the two rivers, sponges, all from the family Spongillidae, order Spongillida, class Demospongiae, were found only at 25 (Fig. 1). Localities of abundance level 1 dominated in both rivers. Only one locality on the Danube (Ram, Serbia) and one on the Sava (Županja, Croatia) had abundance level 3. At the inspected 25 sites, 46 samples were collected. Irrespective of the species, sponges populated waters that were warmer than the average onsite temperature, rich in $\mathrm{O}_{2}$ and higher concentrations of $\mathrm{NO}_{3}$ (Tab. 1). Artificial banks with large stones proved to be the most favorable substrate for sponge growth as specimens were found mostly in such environments.

Light microscope analysis was used for rapid sponge determination. Three spicule categories were observed: megascleres, the main spicules of the sponge skeletal structure, smaller surrounding microscleres and gemmuloscleres, that ensheath gemmules and represent the most valuable identification element (Penney and Racek, 1968; Manconi and Pronzato 2002). Skeletal structure analysis showed that the most prevalent sponges were E. fluviatilis (Linnaeus 1759), S. lacustris (Linnaeus 1759) and Eunapius fragilis (Leidy 1851). Characteristic skeletal elements are given in Fig. 2 a,b. Aberrant spicules were relatively common. No deviation in the number of anomalies could be registered in sponges collected at different sites. In all analyzed specimens the number of spicule anomalies (Fig. 2 c,d) varied between 5 and 15 among roughly 1000 spicules per slide. The number of spicule anomalies probably reflects the levels of heavy 
metals, which varied over a wide range in the two rivers (for instance in the Sava: Cd 0.003-0.020; $\mathrm{Pb} 0.003-0.234$; $\mathrm{Cr} 0.068-0.426 ; \mathrm{Cu} 0.055-0.881$; Ni 0.307-1.07; Zn 0.089-8.74; in the Danube: $\mathrm{Cd}<0.01-0.145 ; \mathrm{Pb} 0.20-8.08$; Cr 0.29-6.73; Cu 1.06-9.93; Ni 0.78-24.63; Zn 1.1312.95; values are given in $\mu \mathrm{g} \mathrm{L}^{-1}$ ) (Krämer and Gawlik, 2015; Dragun et al., 2015).

For several sponges light microscope analysis of their skeletal elements was complemented with SEM (Fig. 3), which allowed for substructures of gemmuloscleres to be more accurately analyzed (Manconi and Pronzato, 2002, 2015; Anđus et al., 2016). E. fluviatilis and T. horrida have gemmuloscleres in the shape of "birotules", two circular elements connected at their centers by a shaft. The indented rotules and shaft visibly longer than the width of rotules is typical of E. fluviatilis (Fig. 3a). Birotules of $T$. horrida with smooth rotule edges and short shafts can be seen in Fig. 3b. Gemmuloscleres of E. fragilis, ranging in size from $95-120 \times 9-12 \mu \mathrm{m}$ are rod-shaped with rounded or pointed tips. They are covered with spines which are often more concentrated distally. Gemmuloscleres of $S$. lacustris, ranging from 50-120 x 5-7 $\mu \mathrm{m}$ are rod-shaped with rounded tips, from almost straight to strongly bent, covered with spines concentrated at the tips (Schletterer and Eggers, 2006). Taxonomy based on morphology was also confirmed by DNA sequencing. Out of 46 samples that were analyzed, 27 gave good quality sequences. Our DNA sequences from specimens of $E$. fluviatilis were 99\% identical with those from GenBank (E. fluviatilis DQ454152, Estonia; EF591285, Italy and JN116226, Israel). DNA sequences of species $E$. fragilis matched with GenBank E. fragilis (DQ454155, Estonia) and sequences of species $S$. lacustris were $99 \%$ identical with sequence of S. lacustris (DQ454154, Estonia) (Tab. 2).

The Neighbor-Joining tree inferred with the alignment of the matrix, including 25 nucleotide sequences of the D3 domain (258 bp) of $28 \mathrm{~S}$ rDNA, revealed three clades within freshwater sponges of above mentioned species, whereas for the out-group the sequence of marine sponge, Scopalina ruetzleri (AY561872) from GenBank was used (Fig. 4). While the tree does not carry enough data to show intraspecific relations it is illustrating the genetic differentiation of 3 prevailing species we encountered.

Within the first clade there are two separations. One contains 14 sequences of the species E. fluviatilis (eight from Serbia, three from Croatia and a single specimen from Estonia, Italy and Israel). The other separation contains three specimens of the species E. fragilis, one from Estonia and two from Croatia and they are presented as three different haplotypes. The second clade contains seven specimens of the species S. lacustris (four from Croatia, two from Serbia and one from Estonia). The two approaches (microscopy and molecular analysis) used in sponge identification coincided in all cases. The distribution of species was as follows: in the Danube River E. fluviatilis was the predominant species making approximately $80 \%$ of collected samples, while $S$. lacustris and E. fragilis represented approximately $10 \%$ of samples each. In the Serbian section of the Danube, on the 5 localities harboring sponges (Ram, Kladovo, Veliko Gradište, Gornji Milanovac, Vinča), only E. fluviatilis was found (12 samples collected and analyzed in total). On the Sava River

Tab. 1. Comparison of minimum, maximum and average values of measured physical and chemical parameters between all localities and localities with sponges in the Sava and the Danube rivers.

\begin{tabular}{|c|c|c|c|c|c|c|}
\hline \multirow{2}{*}{$\begin{array}{l}\text { Danube River } \\
\text { Physical and chemical parameters }\end{array}$} & \multicolumn{3}{|c|}{ General } & \multicolumn{3}{|c|}{ Sponge localities } \\
\hline & Min & Max & Average & Min & Max & Average \\
\hline $\mathrm{pH}$ & 6.73 & 9.03 & 8.1 & 7.89 & 8.26 & 8.09 \\
\hline $\mathrm{t}\left(\mathrm{C}^{\circ}\right)$ & 16.89 & 24.2 & 20.86 & 19.08 & 22.08 & 21.04 \\
\hline conductivity $(\mu \mathrm{S})$ & 195.4 & 1121.9 & 417.17 & 375.3 & 497.9 & 411.76 \\
\hline $\mathrm{O}_{2}(\mathrm{mg} / \mathrm{L})$ & 4.26 & 10.54 & 8 & 5.89 & 9.02 & 7.87 \\
\hline $\mathrm{NO}_{3}(\mathrm{mg} / \mathrm{L})$ & 0.16 & 23.03 & 6.11 & 4.22 & 12.43 & 6.46 \\
\hline $\mathrm{PO}_{4}(\mathrm{mg} / \mathrm{L})$ & 0.1 & 1.54 & 0.21 & 0.13 & 0.23 & 0.16 \\
\hline Sava River & \multicolumn{3}{|c|}{ General } & \multicolumn{3}{|c|}{ Sponge localities } \\
\hline Physical and chemical parameters & Min & Max & Average & Min & Max & Average \\
\hline $\mathrm{pH}$ & 7 & 8.94 & 7.75 & 7 & 8.94 & 7.8 \\
\hline $\mathrm{t}\left(\mathrm{C}^{\circ}\right)$ & 9.9 & 24.8 & 21.1 & 22.4 & 24.8 & 23.2 \\
\hline conductivity $(\mu \mathrm{S})$ & 194 & 587 & 336 & 194 & 587 & 359 \\
\hline $\mathrm{O}_{2}(\mathrm{mg} / \mathrm{L})$ & 5.48 & 10.5 & 8.01 & 6.23 & 9.94 & 7.7 \\
\hline $\mathrm{NO}_{3}(\mathrm{mg} / \mathrm{L})$ & 1.44 & 6.69 & 3.71 & 2.04 & 4.56 & 3 \\
\hline $\mathrm{PO}_{4}(\mathrm{mg} / \mathrm{L})$ & 0.024 & 0.372 & 0.137 & 0.087 & 0.372 & 0.154 \\
\hline
\end{tabular}


localities, the same 3 species were found, but with a different distribution: S. lacustris $(46 \%)$ followed by $E$. fluviatilis (37\%) and E. fragilis (17\%). Only S. lacustris and $E$. fluviatilis have been found in Serbia (Beograd, Novi Beograd, Ostružnica). Županja, Croatia, was the locality with the highest diversity and abundance of sponges. Interestingly, a widely distributed but rare freshwater sponge Trochospongilla horrida, was found on one locality only on the Danube River (Hirsova, Romania).

\section{DISCUSSION}

Sponges are becoming increasingly popular as biological indicators of water quality but have mostly been used in marine environments (Rao et al., 2009; Anakina, 2010; Batista et al., 2013). Consequently, it would be beneficial for countries/regions interested in their use for bio-monitoring purposes to have an overview of their distribution and diversity. This study represents a starting point for future large-scale investigations.

Sampling of sponges along the Danube (from Germany to Romania) and the Sava (from Slovenia to Serbia) revealed a relative paucity of species, as well as low abundance in the majority of examined sites. As far as the Danube is concerned, out of six countries encompassed by the present sampling, sponges were found only in three (Germany, Serbia and Romania). As far as the Sava is concerned, sponges were found in two out of three countries (Croatia and Serbia). This might be due to the fact that not all selected and inspected localities were favorable for sponge development. Namely, absence of adequate growth substrate, faster flow, suboptimal physical and chemical parameters, etc. (Elexová and Némethová, 2003) on a number of river stretches could have had impact on the findings. Four species (E. fluviatilis, S. lacustris, E. fragilis and T. horrida), out of the six species recorded in Central Europe were found.

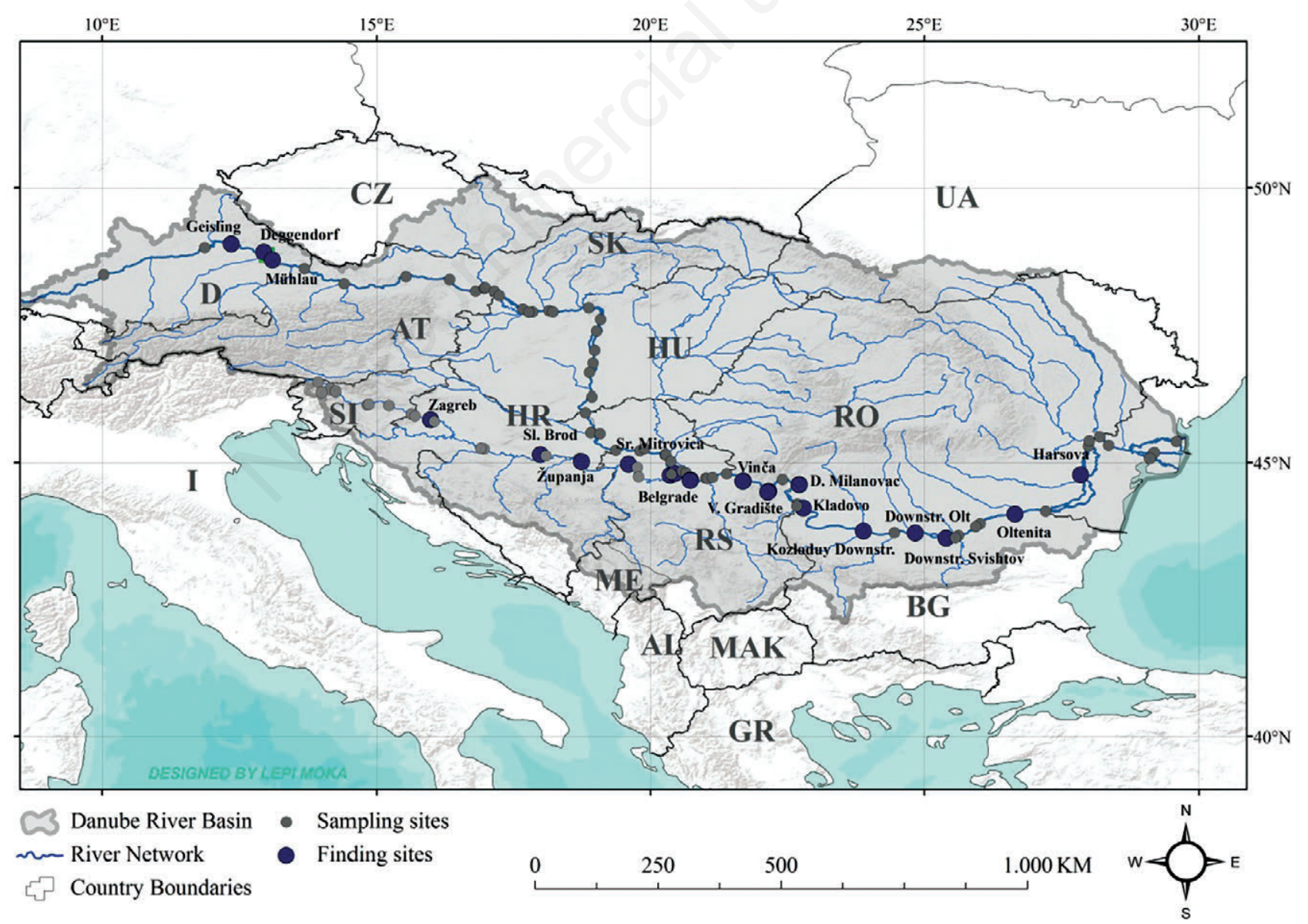

Fig. 1. Approximate distribution of freshwater sponges collected in the framework of Joint Danube Survey 3 investigation (JDS 3 , International Commission for the Protection of the Danube River, 2013) and GLOBAQUA project (Navarro-Ortega et al., 2015) in the period 2013-2015. 
Literature data suggests that species belonging to Ephydatia, Spongilla, and Eunapius are widely distributed (Manconi and Pronzato, 2002, 2008; Manconi et al., 2013) \{Manconi, 2002, Suborder Spongillina subord. nov.: Freshwater Sponges;Manconi, 2008, Global diversity of sponges (Porifera: Spongillina) in freshwater\}, and our findings support this view. In the present study, the same species were found both in the Danube and the Sava rivers, with the exception of $T$. horrida collected at one site only in the Romanian stretch of the Danube. The most prevalent sponge in this river was E. fluviatilis, while in the Sava it was $S$. lacustris. E. fragilis was rare in both rivers. Remarkably, at the inspected localities in Austria, no sponges were found. This is in contrast with the results of Dröscher and Waringer who found 5 species in the Danubian floodplain waters near Vienna (E. fluviatilis, $S$. lacustris, E. muelleri, E. fragilis and T. horrida). It must be emphasized however, that our sampling did not include the area around Vienna, which may explain data discrepancy. These authors also noted that E. fluviatilis favored water temperatures over $21^{\circ} \mathrm{C}$, which is in agreement with our findings regarding temperatures characterizing sponge habitats. From its source in the Slovenian mountains to its mouth into the Danube in Serbia, with its total length of $944 \mathrm{~km}$ and total catchment area of $97,713 \mathrm{~km}^{2}$, the Sava River represents one of Europe's ecologically most interesting lifelines. As previously stated, several international surveys have been conducted on the Sava River Basin; yet, sponges have never been in the focus of investigations. In the Slovenian stretch of the Sava river there were no sponges, in Serbia they were scarce (abundance level 1 on all sites), while in Croatia, near Županja, three species were present (abundance level 3).

In addition to the Ramsar Convention document (2008) and the exhaustive Sava River monograph (Milačič, 2015), where sponges are only mentioned, this study represents the first screening of freshwater sponges in Serbia, and it appears that they are infrequent and their diversity limited. This is not an uncommon phenomenon in European running and still waters: in the Ebro River Basin (Spain), only E. fluviatilis and E. fragilis were recorded (Oscoz et al., 2009), and in the Temo River (Sardinia, Italy) E. fluviatilis was the single species collected (Manconi and Pronzato, 1994; Cubeddu et al., 1995). Interestingly, in the Rhine during the seventies only E. fluviatilis could be found, although beyond that period, other species were also present (Gugel, 2001). Similarly, in the Serbian portion of the Danube, E. fluviatilis was the sole registered species. Remarcably, T. horrida was found at one site only in the Romanian portion of the Danube, which is in sharp contrast with the Volga river, where it represents the most common sponge (Schletterer, 2006). Based on physico-chemical data, sponges showed

Tab. 2. Details of collected species and GenBank accession numbers sequences of the used freshwater sponges for $28 \mathrm{~S}$ rDNA.

\begin{tabular}{lll} 
Taxon & Locality & Specimen code \\
Family Spongillidae & & \\
Spongilla lacustris & Serbia; Sava & \\
Spongilla lacustris & Serbia; Sava & AS37 \\
Spongilla lacustris & Croatia, Sava & AS40 \\
Spongilla lacustris & Croatia, Sava & AS41 \\
Spongilla lacustris & Serbia; Sava & AS46 \\
Spongilla lacustris & Serbia; Sava & AS48 \\
Spongilla lacustris & Estonia & \\
\hline Eunapius fragilis & Serbia; Sava & DQ454154 \\
Eunapius fragilis & Serbia; Sava & AS44 \\
Eunapius fragilis & Estonia & AS45 \\
\hline Ephydatia fluviatilis & Serbia; Danube & \\
Ephydatia fluviatilis & Serbia; Danube & DQ454155 \\
Ephydatia fluviatilis & Serbia; Danube & AS30 \\
Ephydatia fluviatilis & Serbia; Danube & AS31 \\
Ephydatia fluviatilis & Serbia; Danube 32 \\
Ephydatia fluviatilis & Serbia; Danube & AS33 \\
Ephydatia fluviatilis & Serbia; Sava & AS34 \\
Ephydatia fluviatilis & Croatia, Sava & AS35 \\
Ephydatia fluviatilis & Croatia, Sava & AS38 \\
Ephydatia fluviatilis & Croatia, Sava & AS39 \\
Ephydatia fluviatilis & Croatia, Sava & AS42 \\
Ephydatia fluviatilis & Estonia & AS43 \\
Ephydatia fluviatilis & Italy & AS46 \\
Ephydatia fluviatilis & Israel & \\
\hline & & \\
\hline
\end{tabular}



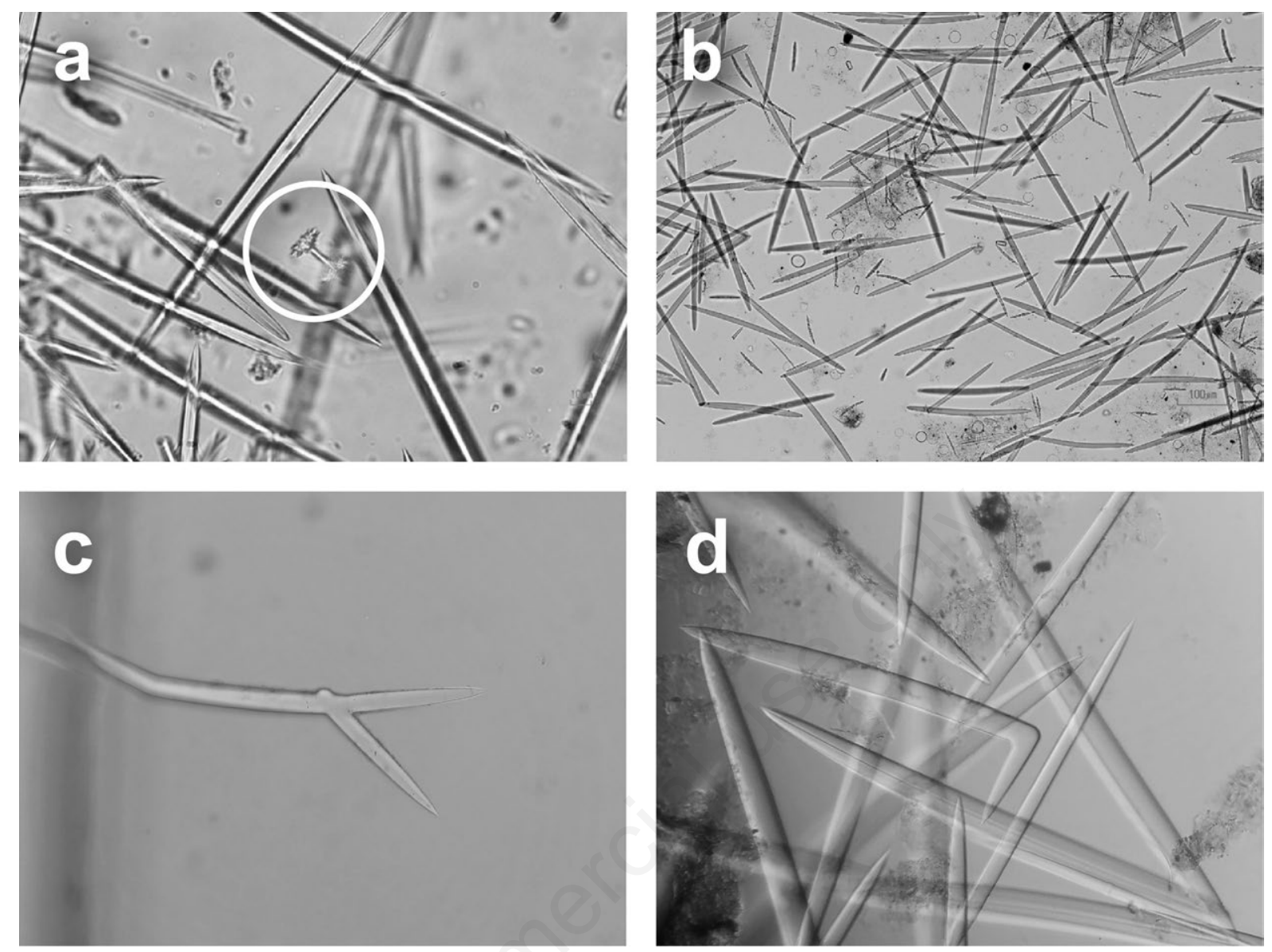

Fig. 2. a) Typical skeletal structures of Ephydatia fluviatilis: long and smooth monaxial oxea (megascleres) and birotule (gemmulosclere) with characteristic starshaped rotules and shaft longer than the width of the rotules. b) Typical skeletal structures of Spongilla lacustris: smooth oxea (megascleres) and thorny microscleres and gemmuloscleres. c,d) Representative spicules with anomalies.
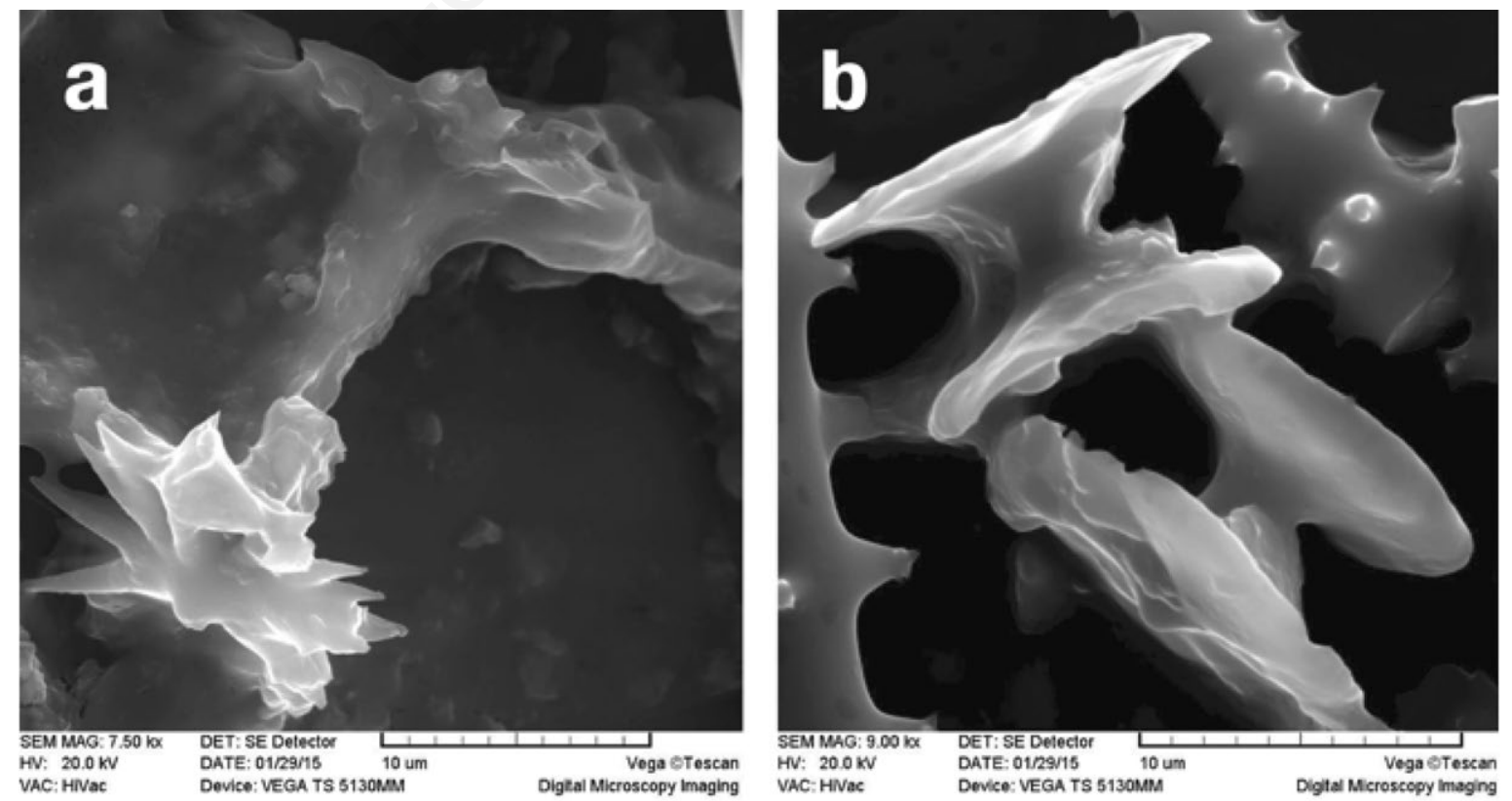

Fig. 3. SEM images of: a) E. fluviatilis gemmulosclere (birotule); b) two birotules of T. horrida. 
preference toward slightly alkaline and well oxygenated water, higher water temperatures and conductivity, higher concentrations of $\mathrm{NO}_{3}$, and lower concentrations of $\mathrm{PO}_{4}$. This is generally in line with some previous studies (Richelle-Maurer et al., 1994). It has also been shown that sponges may grow in relatively polluted water which is the case with Sava and Danube. Levels of anthropogenic pollution vary considerably along the river courses, but it is considered that the permitted concentrations of heavy metals are usually not exceeded. Even in heavily industrialized zones with poor wastewater treatment, Intervention Values were not reached (Antonijević MD et al., 2013). The presence of pollutants might account, among other, to spicule malformations found in sponges of both rivers at all inspected sites, without striking difference in malformation number between the sites.

\section{CONCLUSIONS}

Based on this study, one of the few dealing with sponges in the Danube and the Sava, both rivers are characterized by a rather low abundance of porifera with a limited diversity of species.

Further studies on a larger scale, possibly collected in a wider time-window, are needed for a more reliable overview of the distribution of these organisms in Danube and Sava rivers.

\section{ACKNOWLEDGMENTS}

The study was supported by the Ministry of Education, Science and Technological Development of the Republic

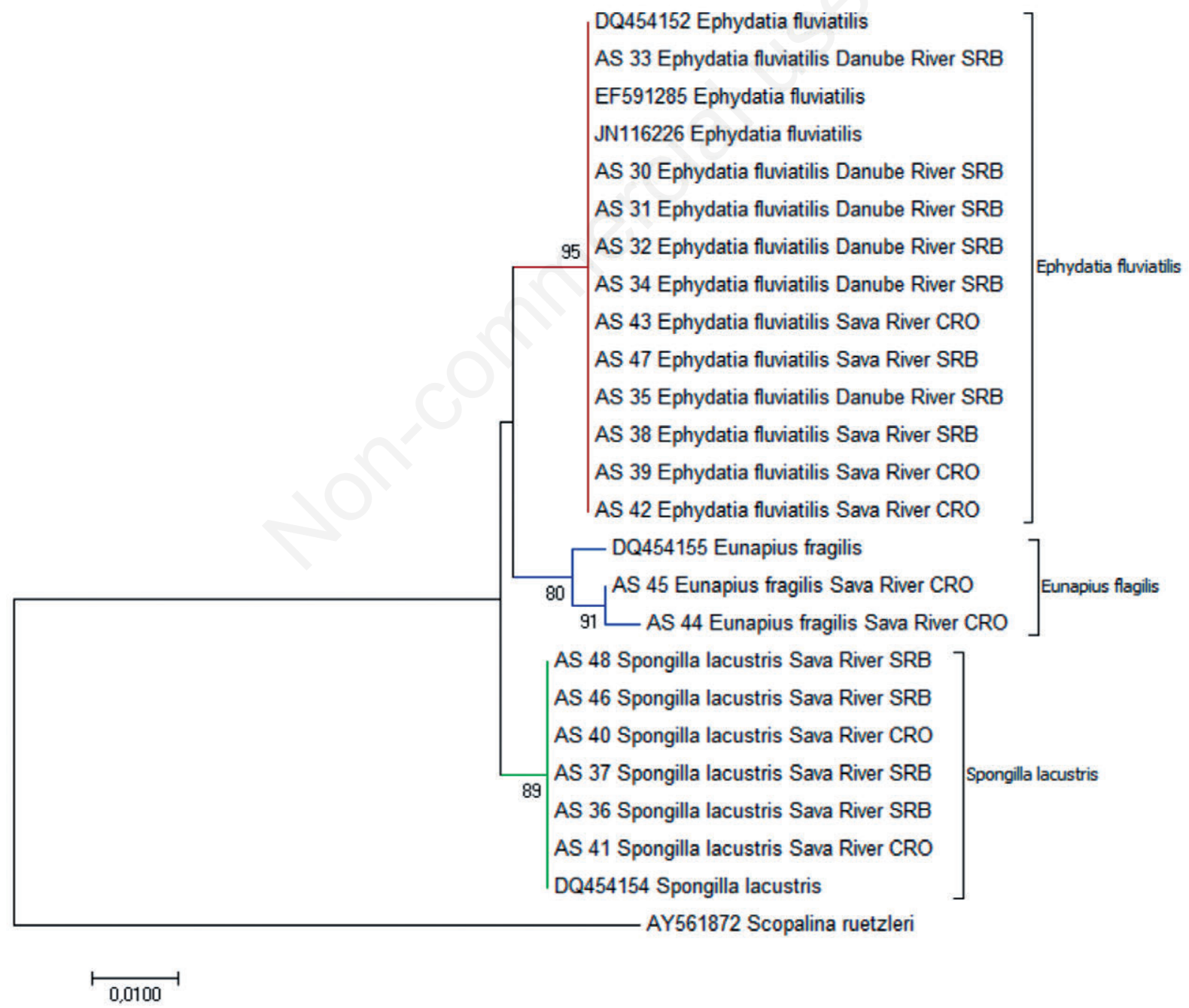

Fig. 4. Phylogenetic trees based on the D3 domain of $28 \mathrm{~S}$ rDNA obtained using the Neighbor-Joining (NJ) method. Bootstrap values are indicated below the branches. The scale bar indicates the number of substitutions per site. 
of Serbia, Grants No. 176018, and the European Union's Seventh Framework Programme under grant agreement No 603629-ENV-2013-6.2.1-GLOBAQUA. Part of the material for this study was collected during the Joint Danube Survey 3 expedition, under the coordination of the International Commission for the Protection of the Danube River (ICPDR) and with the financial contribution of the "Danubian" countries and the European Commission. We would like to express our gratitude to all participants in the JDS3 expedition, with special acknowledgement for the assistance of the Secretariat General of the ICPDR for its support during the investigation. We express our thanks to Dr. Goran Poznanović for his constructive comments and English proof reading.

\section{REFERENCES}

Anakina R, 2010. Sponges as biological indicators and remedial components of freshwater ecological systems. Biosphere 2:397-408.

Anđus S, Tubić B, Ilić M, Đuknić J, Gačić Z, Paunović M, 2016. Freshwater sponges-skeletal structure analysis using Light Microscopy and Scanning Electron Microscopy. Water Res. Manage. 6:15-17.

Antonijević MD, Arsović M, Č́slavský J, Cvetković V, Dabić P, Franko M, Ilić G, Ivanović M, Ivanović N, Kosovac M, Medić D, 2013. Actual contamination of the Danube and Sava rivers at Belgrade. J. Serbian Chem. Soc. 79:1169.

Arndt W, 1926. [Die Spongillidenfauna Europas].[Article in German]. Arch. Hydrobiol. 17:337-365.

Arndt W, 1931. [Die Süsswasserschwämme des arktischen Gebietes].[Article in German]. Fauna arct. 6:35-40.

Arndt W, 1932a. [Die Süsswasserschwammfauna Norwegens]. [Article in German]. Nytt Mag. Naturv. 70:299-312.

Arndt W, 1932b. [Die Süsswasserschwammfauna Schwedens, Finnlands und Dänemarks].[Article in German]. Ark. Zool. 24A:1-33.

Bănărescu PM, 2004. Distribution pattern of the aquatic fauna of the Balkan Peninsula, p. 203-217. In: H.I. Griffiths, B.s Kryštufek and J.M. Reed (eds.), Balkan biodiversity: Pattern and process in the European hotspot. Springer.

Batista D, Tellini K, Nudi AH, Massone TP, Scofield ADL, De Lr Wagener A, 2013. Marine sponges as bioindicators of oil and combustion derived PAH in coastal waters. Mar. Environ. Res. 92:234-243.

Bilandžija H, Bedek J, Jalžić B, Gottstein S, 2007. The morphological variability, distribution patterns and endangerment in the Ogulin cave sponge Eunapius subterraneus Sket \& Velikonja, 1984 (Demospongiae, Spongillidae). Natura Croatica: Periodicum Musei Historiae Naturalis Croatici 16:1-7.

Croatian Water Managemant Plan, 2013. [Plan upravljanja vodnim podruĉjima, Annex I].[Report in Croatian]. Available from: http://www.voda.hr/sites/default/files/dokumenti/dodatak1.pdf

Cubeddu T, Deriu A, Sechi A, Manconi R, 1995. [Spongillidi (Porifera, Demospongiae) del Fiume Temo (Sardegna nordoccidentale)].[Article in Italian]. Boll. Società Sarda Scienze Naturali 30:41-51.
Dragun Z, Filipović Marijić V, Vukovic M, Raspor B, 2015. Metal bioavailability in the Sava River water, p. 123-155. In: R. Milačić, J. Ščančar and M. Paunović (eds.), The handbook of environmental chemistry. The Sava River. Springer, Dordrecht.

Dorschner J, Dreyer U, Gugel J, Guhr H, Kinzelbach R, Meister A, Seel P, 1993. [Der Gewässerzustand der Elbe 1991. Ergebnisse einer Bereisung mit dem hessischen Meß-und Laborschiff'Argus' zwischen Veletov und Geesthacht]. [Book in German]. Hessische Landesamst für Umwelt, Wiesbaden: $99 \mathrm{pp}$.

Dröscher I, Waringer J, 2007. Abundance and distribution of freshwater sponges (Spongillidae) in Danube floodplain waters near Vienna, Austria. Freshwater Biol. 52:998-1008.

Elexová E, Némethová D, 2003. The effect of abiotic environmental variables on the Danube macrozoobenthic communities. Limnologica 33:340-354.

Felsenstein J, 1985. Confidence limits on phylogenies: an approach using the bootstrap. Evolution 39:783-791.

Francis JC, Poirrier MA, 1986. Particle uptake in two fresh-water sponge species, Ephydatia fluviatilis and Spongilla alba (Porifera: Spongillidae). T. Am. Microsc. Soc. 105:11-20.

Frost TM, 1978. In situ measurements of clearance rates for the freshwater sponge Spongilla lacustris. Limnol. Oceanogr. 23:1034-1039.

Graf W, Csányi B, Leitner P, Paunović M, Huber T, Szekeres J, Nagy C, Borza P, 2015. Macroinvertebrates, p. 81-99. In: I. Liška, F. Wagner, M. Sengl, K. Deutsch and J. Slobodník (eds.), Joint Danube survey. A comprehensive analysis of Danube water quality. ICPDR, Vienna.

Gugel J, 2001. Life cycles and ecological interactions of freshwater sponges (Porifera, Spongillidae) in the River Rhine in Germany. Limnologica 31:185-98.

Hadzisce S, 1953. [Beitrag zur Kenntnis der Spongillidenfauna der großen mazedonischen Seen (Dojran, Prespa und Ohridsee)].[Book in Macedonian]. Recueil des Traveaux. Station Hydrobiologique Ohrid 1:73-103.

Itskovich V, Kaluzhnaya O, Ostrovsky I, Mccormack G, 2013. The number of endemic species of freshwater sponges (Malawispongiidae; Spongillina; Porifera) from Lake Kinneret is overestimated. J. Zool. Syst. Evol. Res. 51:252-257.

Jakhalekar SS, Ghate H, 2013. A note on five freshwater sponges (Porifera: Spongillina: Spongillidae) from Pune, Maharashtra, India. J. Threat. Taxa 5:4392-4403.

Kimura M, 1980. A simple method for estimating evolutionary rates of base substitutions through comparative studies of nucleotide sequences. J. Mol. Evol.16:111-120.

Krämer D, Gawlik B, 2015. Metals, p. 223-239. In: I. Liška, F. Wagner, M. Sengl, K. Deutsch and J. Slobodník (eds.), J Joint Danube survey. A comprehensive analysis of Danube water quality. ICPDR, Vienna.

Kumar S, Stecher G, Tamura K, 2016. MEGA7: Molecular Evolutionary Genetics Analysis version 7.0 for bigger datasets. Mol. Biol. Evol. 33:1870-1874.

Lévêque C, Balian E, Martens K, 2005. An assessment of animal species diversity in continental waters. Hydrobiologia 542:39-67.

Lopp A, Reintamm T, Vallmann K, Päri M, Mikli V, RichelleMaurer E, Kelve M, 2007. Molecular identification, characterization and distribution of freshwater sponges 
(Porifera: Spongillidae) in Estonia. Arch. Hydrobiol. 168:93-103.

Lucić A, Paunović M, Tomović J, Kovačević S, Zorić K, Simić V, Atanacković A, Marković V, Kračun-Kolarević M, Hudina S, Lajtner J, Gottstein S, Milošević Đ, Anđus S, Žganec K, Jaklič M, Simčič T, Vilenica M, 2015. Aquatic macroinvertebrates of the Sava River, p. 335-359. In: R. Milačić, J. Ščančar and M. Paunović (eds.), The handbook of environmental chemistry. The Sava River. Springer, Dordrecht.

Manconi R, Desqueiroux-Faundez R, 1999. Freshwater sponges (Porifera, Spongillidae) from the Lake of Geneva, Switzerland. Rev. Suisse Zool. 106:571-80.

Manconi R, Pronzato R, 1994. Spongillids of Mediterranean islands, p. 333-340. In: R.W.M. van Soest, T.M.G. van Kempen and J.C. Braekman (eds.), Sponges in time and space. Routledge, London.

Manconi R, Pronzato R, 2002. Suborder Spongillina subord. nov.: Freshwater sponges, p. 921-1019. In: J.N.A. Hooper, R.W.M. Van Soest and P. Willenz (eds.), Systema Porifera: A guide to the classification of sponges. Springer, New York.

Manconi R, Pronzato R, 2007. Gemmules as a key structure for the adaptive radiation of freshwater sponges: a morphofunctional and biogeographical study, p. 61-77. In: M.R. Custódio, G. Lôbo-Hajdu, E. Hajdu and G. Muricy (eds.), Porifera research: biodiversity, innovation and sustainability. Museu Nacional, Rio de Janeiro.

Manconi R, Pronzato R, 2008. Global diversity of sponges (Porifera: Spongillina) in freshwater. Hydrobiologia 595: 27-33.

Manconi R, Pronzato R, 2015. Phylum Porifera, p. 133-157. In: J. Thorp and D.C. Rogers (eds.), Ecology and general biology: Thorp and Covich's freshwater invertebrates. Academic Press, Cambridge.

Manconi R, Pronzato R, 2016. Phylum Porifera, p. 39-84. In: J. Thorp and D.C. Rogers (eds.), Keys to Nearctic fauna: Thorp and Covich's freshwater invertebrates. Academic Press, Cambridge.

Manconi R, Ruengsawang N, Vannachak V, Hanjavanit C, Sangpradub N, Pronzato R, 2013. Biodiversity in South East Asia: an overview of freshwater sponges (Porifera: Demospongiae: Spongillina). J. Limnol. 72(Suppl.2):313-326.

Matoničkin I, Pavletić Z, Habdija I, Stilinović B, 1975. [Prilog valorizaciji voda ekosistema rijeke Save].[Book in Croatian] Sveučilišna Naklada Liber 95.

Mihaljević Z, Kerovec M, Tavčar V, Bukvić I, 1998. Macroinvertebrate community on the artificial substrate in the Sava River: long-term changes in the community structure and water quality. Biologia (Bratislava) 53:611-20.

Milačič R, Ščančar J, Paunović M, 2015. The Handbook of environmental chemistry. The Sava River. Springer, Dordrecht.

Morrow CC, Redmond NE, Picton BE, Thacker RW, Collins AG, Maggs CA, Sigwart JD, Allcock AL, 2013. Molecular phylogenies support homoplasy of multiple morphological characters used in the taxonomy of Heteroscleromorpha (Porifera: Demospongiae). Integr. Comp. Biol. 53:428-446.

Navarro-Ortega A, Acuña V, Bellin A, Burek P, Cassiani G, Choukr-Allah R, Dolédec S, Elosegi A, Ferrari F, Ginebreda A, 2015. Managing the effects of multiple stressors on aquatic ecosystems under water scarcity. The GLOBAQUA project. Sci. Total Environ. 503:3-9.

Oscoz J, Tomás P, Durán C, 2009. New records of Eunapius fragilis (Leidy, 1851) and Ephydatia fluviatilis (Linnaeus, 1759) (Porifera, Spongillidae) in Ebro River Basin ( $N$ Spain). Limnetica 28:185-188.

Økland KA, Økland J, 1996. Freshwater sponges (Porifera: Spongillidae) of Norway: distribution and ecology. Hydrobiologia 330:1-30.

Penny JT, Racek AA, 1968. Comprehensive revision of a worldwide collection of freshwater sponges (Porifera: Spongillidae). U.S. Nat. Mus. Bull. 272:1-184.

Rao JV, Srikanth K, Pallela R, Rao TG, 2009. The use of marine sponge, Haliclona tenuiramosa as bioindicator to monitor heavy metal pollution in the coasts of Gulf of Mannar, India. Environ. Monit. Assess. 156:451-459.

Richelle-Maurer E, Degoudenne Y, Van de Vyver G, Dejonghe L, 1994. Some aspects of the ecology of Belgian freshwater sponges, p. 341-350. In: J.-C. Braekman, T.M.G. van Kampen and R.W.G. van Soest (eds.), Sponges in time and space. Routledge, London.

Richelle E, Degoudenne Y, Dejonghe L, Van de Vyver G, 1995. Experimental and field studies on the effect of selected heavy metals on three freshwater sponge species: Ephydatia fluviatilis, Ephydatia muelleri and Spongilla lacustris. Arch. Hydrobiol. 135:209-31.

Roovere T, Loppa A, Reintamma T, Kuusksalua A, RichelleMaurerc E, Kelvea M, 2006. Freshwater sponges in Estonia: genetic and morphological identification, p. 216-227. Proceedings Estonian Academy of Sciences, Biology and Ecology. Estonian Academy.

Rudescu L, 1975. [Porifera Potamospongiae].[Book in Romanian]. Fauna Rep. Soc. Romania. Editura Academiei Republicii Socialiste România, Bucuresti: 115 pp.

Saitou N, Nei M, 1987. The neighbor-joining method: a new method for reconstructing phylogenetic trees. Mol. Biol. Evol. 4:406-425.

Schletterer M, Eggers TO, 2006. Evidence of freshwater sponges (Porifera: Spongillidae) in the Upper Volga River (Russia). Ber.-Nat. Med. Vereins Innsbruck 93:73-84.

Tendal OS, 1967a. On the freshwater sponges of Denmark. Videns. Meddel. Dansk Naturhist. For. 130:173-8.

Tendal OS, 1967b. [Ferskvandssvampe (Spongillidae) i Thy].[Article in Norwegian]. Flora og Fauna 73:63-67.

Tendal OS, 1976. Freshwater spongia. Zoology Iceland 2(4a):1-4.

Traveset A, 1990. Notes on Iberian freshwater sponges, p. 320322. In: K. Rutzler (ed.), New perspectives in sponge biology. Proceedings 3rd Int. Sponge Conf. 1985. Smithsonian Institution Press, Washington DC.

Van Soest RW, Boury-Esnault N, Vacelet J, Dohrmann M, Erpenbeck D, De Voogd NJ, Santodomingo N, Vanhoorne B, Kelly M, Hooper JN, 2012. Global diversity of sponges (Porifera). PLoS One 7:e35105.

Volkmer-Ribeiro C, Machado VDS, 2007. Freshwater sponges (Porifera, Demospongiae) indicators of some coastal habitats in South America: redescriptions and key to identification. Iheringia. Série Zoologia 97:157-167.

Ramsar Convention, 2008. Zasavica river ecosystem named for the Ramsar List. Available from: https:/www.ramsar.org/ news/zasavica-river-ecosystem-named-for-the-ramsar-list 